\title{
ANALYSIS OF VARIATION AMONG GENOTYPES OF FLUTED PUMPKIN (TELFAIRIA OCCIDENTALIS HOOK. F) USING FACTOR ANALYSIS AND PRINCIPAL COMPONENT ANALYSIS (PCA)
}

\author{
Ifeoma Sussan Ezenwata \\ Department of Biological Sciences \\ Chukwuemeka Odumegwu Ojukwu \\ University, Uli, Anambra, Nigeria
}

\section{Sunday Clement Olubunmi Makinde \\ Department of Botany}

Lagos State University, Ojo, Lagos, Nigeria

\section{Rachael Chinweoke Ogbuoka}

Department of Botany

Lagos State University, Ojo, Lagos, Nigeria,

\begin{abstract}
This study aimed at investigating genetic divergence in twenty genotypes of fluted pumpkin (Telfairia occidentalis) and determines the characters responsible for the variation. The twenty genotypes were collected from different locations within southern Nigeria (Anambra, Enugu, Lagos, Ondo and Ogun). The experiment was carried out at the Lagos State University Botanical Garden using a Randomized Block Design (RBD) with three replications. The collected data were subjected to Principal Component Analysis (PCA) and Factor Analysis to evaluate the patterns of variation in these genotypes. Two out of the twenty four principal components had eigen values greater than 2.0. The first five principal component jointly accounted for $88.61 \%$ of the total variation among the genotypes. Twenty factors were identified. The first two factors had eigen value of 5.28 and 2.05 respectively while only four factors accounted for $81.47 \%$ of the total variance. The two analysis methods indicated vine length, leaf size, number of branches, vine diameter, number of leaves, petiole length as traits that contributed more to the total variation observed and as such can be used in discriminating among the genotypes. Configurations of the 20 genotypes along the first three principal component axes shows that L4, N4, N3, O1, E1, A1, N1 and A3 were most distant from all
\end{abstract}

\author{
Regland Michael Onyemeka \\ Department of Botany
Lagos State University, Ojo, Lagos, Nigeria \\ Lagos State University, Ojo, Lagos, Nigeria
}

Chiamaka Frances Anyaegbu

Department of Biological Sciences

Chukwuemeka Odumegwu Ojukwu University, Uli, Anambra, Nigeria

\author{
Opeyemi Shakirat Oyetunji \\ Department of Botany \\ Lagos State University, Ojo, Lagos, Nigeria
}

other genotypes and are high yielding in terms of vine length, number of branches and leaf size therefore can be selected directly. The complementarity effect of the principal component analysis and factor analysis, suggest the existence of genetic variability among the genotypes.

Keywords- Multivariate, variability, Principal Component Analysis, Factor Analysis.

\section{INTRODUCTION}

In Nigeria, vegetable production has been on-going for decades, providing employment and income for the increasing population especially during the long dry season. Among the important indigenous vegetables, Telfairia occidentalis (Hook. F.) (fluted pumpkin) seems to be widely cultivated for its edible succulent shoots and leaves as a backyard crops mainly by the Igbo tribe (Akoroda, 1990). It is a member of the curcurbitaceae family. It originated from tropical West Africa (Irvine 1969; Esiaba, 1983) and is indigenous to southern Nigeria (Akoroda, 1990, Akanbi et al., 2007; Odiaka et al., 2008). The plant is a droughttolerant, dioecious perennial that is usually grown trellised. It is an herbaceous perennial crop, although it is cultivated as an annual crop especially under the traditional farming system in 


\section{International Journal of Engineering Applied Sciences and Technology, 2019 \\ Vol. 4, Issue 7, ISSN No. 2455-2143, Pages 211-216 \\ Published Online November 2019 in IJEAST (http://www.ijeast.com)}

West Africa. T. occidentalis is traditionally used by an estimated 30 to 35 million indigenous people in Nigeria (Akoroda, 1990). However, it was predominantly used by the Igbo tribe, who continue to cultivate the gourd for food sources and traditional medicines (Okoli and Mgbeogu, 1983). Consumers prefer the vegetable because of its ability to remain green and its better texture in soup for longer time compared with others. The crop is also cultivated for its seed that is rich in oil and used as thickeners in soup. The leaf extract is believed to serve as a remedy to anemia, high blood pressure, convulsion and diabetes (Okoli and Mgbeogu, 1983; Ehiagbonare, 2008). It has been suggested that the ability of the plant to combat certain diseases may be due to its antioxidant and antimicrobial properties and its mineral (especially iron), vitamins (especially Vitamins A and C) and high protein contents (Kayode and Kayode, 2011).

In spite of these desirable attributes exhibited by $T$. occidentalis, little is known about attempts to improve the crop. Also, any attempts to improve the crop can only be possible if there is sufficient genetic variability in characters that are of economic interest. Therefore, the starting point for the improvement programme of the fluted pumpkin is to determine the amount, cause and nature of variation that is present within the population. The understanding of variability in fluted pumpkin of various accessions will therefore enhance our exploitation of these benefits.

Multivariate statistical methods (such as principal component analysis (PCA), cluster analysis, factor analysis, canonical analysis, discriminant analysis; Mahalanobis squared distance ( $\mathrm{D}^{2}$ Statistics) and multidimensional scaling) are utilized in estimating genetic diversity accurately. These methods analyze multiple measurements simultaneously on each individual genotype under investigation and also determine the character which causes the diversity to arise among the genotypes under study as well as the relative contributions of such characters to the total variability in the germplasm (Odiyi et al., 2014). It has been used successfully studying the variation patterns in populations of crop genotypes (Rhodes and Martins, 1972; Ariyo et al., 1987; Raji, 2003; Nassir and Ariyo, 2007; Makinde and Ariyo, 2010; Fayeun, 2011; Fayeun and Odiyi, 2012 and Odiyi et al., 2014). Factor Analysis aside serving as means of identifying fundamental and meaningful dimensions of a multivariate set of data, it assumes that a small number of observed construct are responsible for the correlation among a large number of observed variables (Cooley and Lohnes, 1971, (Bramel et al., 1984). Principal component analysis reduces data to clarify the relationship between two or more characters and partitions the total variance of the original characters into uncorrelated new variables (Wiley, 1981).

This study aimed at investigating genetic divergence in twenty genotypes of fluted pumpkin (T. occidentalis) and determines the characters responsible for the variation using Factor and Principal component analysis.

\section{MATERIALS AND METHODS}

The experiment was carried out at the Botanical Garden of the department of Botany, Lagos State University, Ojo, Lagos, Nigeria.

A. Plant materials: Twenty land races or genotype (pods) of matured fluted pumpkin fruits were obtained from five states in South East (Anambra and Enugu States) and South West (Ondo, Lagos and Ogun States) region of Nigeria. Table 1 contains the genotype coding and state of collection.

Table 1: Genotype coding and state of collection of the $20 \mathrm{~T}$. occidentalis genotypes

\begin{tabular}{ccc}
$\begin{array}{c}\text { Genotype } \\
\text { number }\end{array}$ & Genotype code & State of collection \\
\hline V1 & A1 & Anambra \\
V2 & A2 & Anambra \\
V3 & A3 & Anambra \\
V4 & A4 & Anambra \\
V5 & E1 & Enugu \\
V6 & E2 & Enugu \\
V7 & E3 & Enugu \\
V8 & E4 & Enugu \\
V9 & O1 & Ogun \\
V10 & O2 & Ogun \\
V11 & O3 & Ogun \\
V12 & O4 & Ogun \\
V13 & L1 & Lagos \\
V14 & L2 & Lagos \\
V15 & L3 & Lagos \\
V16 & L4 & Lagos \\
V17 & N1 & Ondo \\
V18 & N2 & Ondo \\
V19 & N3 & Ondo \\
V20 & N4 & Ondo \\
\hline
\end{tabular}

B. Experimental design, procedure and management: The experimental design was Randomized Block Design (RBD) with three replicates. The main plot measures $7 \mathrm{~m} \times 10 \mathrm{~m}$ and the sub plots were single row plants of $1 \mathrm{~m} \times 10 \mathrm{~m}$. Plot spacing was $1 \mathrm{~m}$ each between and within rows.

Planting: After necessary data's were collected on the pods and seeds, pods from the five states were randomized within the main plots; ten seeds were selected randomly from each pod and planted.

Cultural Practices: Manual weeding was carried out at intervals of 2 weeks while fertilizer NPK 15:15:15 at the rate of $30 \mathrm{~g}$ per plant was applied using ring method of application to increase the fertility of the soil.

C. Data collection and analysis: 10 quantitative data were collected on all the accessions after establishment. Ten competitive plants from the two middle rows in each plot were harvested and observations were taken on the following quantitative characteristic; Days to emergence, Vine length 2 


\section{International Journal of Engineering Applied Sciences and Technology, 2019 Vol. 4, Issue 7, ISSN No. 2455-2143, Pages 211-216 \\ Published Online November 2019 in IJEAST (http://www.ijeast.com)}

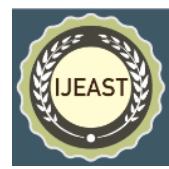

weeks after planting (WAP), Number of leaves 2 weeks after planting (WAP), Vine length 6 weeks after planting (WAP), Number of leaves 6 weeks after planting (WAP), Number of branches 6 weeks after planting (WAP), Vine diameter 6 weeks after planting (WAP), Leaf length 6 weeks after planting (WAP), Leaf width 6 weeks after planting (WAP), Leaf area 6 weeks after planting (WAP), Petiole length 6 weeks after planting (WAP) $(\mathrm{cm})$ and Internode length 6 weeks after planting (WAP).

\section{RESULTS}

\section{Factor Analysis}

Twenty factors were identified, out of which only four were considered important. Table 2 indicates the factor scores, total variance, eigen values and Communality scores. These four factors accounted for $81.47 \%$ of the total variance. The first factor with eigen value of 5.28 explained $44.04 \%$ of the variance and second factor with eigen value of 2.05 explained $17.05 \%$ of the variance. The third, fourth and fifth factors had eigen value of $1.34,1.10$ and 0.86 and explained $11.18 \%$, $9.20 \%$ and $7.14 \%$ variance respectively. The first factor was highly positively loaded for vine length 2 WAP $(0.77)$, number of leaves 2 WAP (0.78), vine length 6WAP (0.73), number of leaves 6WAP (0.70), leaf length 6WAP (0.82), leaf width 6WAP (0.80) and leaf area 6WAP (0.83). The second factor was highly positively loaded for vine length 6WAP (0.61) and petiole length 6WAP (0.63) but negatively loaded for leaf length 6WAP (-0.51), leaf width 6WAP (-0.54) and leaf area 6WAP (-0.51). The third factor was positively loaded for number of branches 6WAP (0.66) and vine diameter 6WAP (0.53) but negatively loaded for days to emergence $(-0.51)$ while the fourth factor was loaded for vine diameter 6WAP (0.56). The Communality ranged from 0.62 for vine diameter 6WAP to 0.98 for leaf area 6WAP. High communalities were associated with characters related to leaf size, in particular; leaf area 6WAP (0.98), leaf width 6WAP (0.97) and leaf length 6WAP (0.95).

\section{Principal Component Analysis (PCA)}

The scores of the major characters describing the first five principal component axes are presented in Table 2. Two out of the twenty four principal components had eigen values greater than 2.0 (Table 2). The first five principal component axes jointly accounted for $88.61 \%$ of the total variation among the genotypes studied. The first principal component axis (PC1) accounted for $44.04 \%$ of the total variation. It was positive and significantly loaded with all the traits except days to emergence, number of branches 6WAP and vine diameter 6WAP. PC2 was positively significant for vine length 6WAP (0.43), number of leaves 6WAP (0.30) and Petiole length 6WAP (0.44) but negatively correlated with leaf size related traits such as; leaf length 6WAP (-0.36), leaf width 6WAP ($0.38)$ and leaf area 6WAP $(-0.36)$. Vine diameter 6WAP was positively loaded in PC3 (0.46), PC4 (0.53) and PC5 (0.63). Number of leaves 6WAP was positively loaded in PC3 $(0.57)$ and negatively loaded in PC5 (-0.59) while internode length 6 WAP positively loaded in PC3 and negative in PC4 (-0.41). Configurations of the 20 genotypes along the first three principal component axes are shown in Figures 1, 2 and 3. The ordination of the genotypes on axes 1 and 2 (Figure 1) shows that L4, N4, N3, O1, E1 and A1 were most distant from all other genotypes. The grouping of genotypes in Figure 1 was determined by characters (especially vine length and leaf size) associated with PC1 and PC2. Figure 2 displayed the graphing of axes 1 and 3 and showed that genotype N4, N3, N1, A3, E1 and A1 were distinct from other genotypes. They were described by the following characters; vine length, leaf size, days to emergence, number of branches and vine diameter associated with PC1 and PC3. Figure 3 shows another configuration of the genotypes (axes 2 and 3) where N4, N3, N1, A3, E1 and A1 distinguished themselves from all other genotypes.

\section{DISCUSSION}

Multivariate analysis is useful because it determines the plant characters that cause the dissimilarity to arise and the relative contributions of the various characters to the total variability in the germplasm (Ariyo, 1993). The results, as captured by the complementarity effect of the principal component analysis and factor analysis, suggest the existence of genetic variability among the genotypes studied. Factor analysis and principal component analysis identified some similar characters as the most important for classifying the variation among the 20 genotypes. The two analysis methods indicated vine length, leaf size, number of branches, vine diameter, number of leaves, petiole length as traits that contributed more to the total variation observed and as such can be used in discriminating among the genotypes. Importance of vine length at harvest and number of branches per plant has been reported in fluted pumpkin by Odiyi et al. (2014) and other crops (Ariyo, 1995; Aremu et al., 2007). The similarity between the two techniques had been reported earlier in fluted pumpkin by Odiyi et al. (2014), okra by Ariyo (1993), rice by Nassir and Ariyo (2007) and groundnut by Makinde and Ariyo (2010). Although, the two techniques produced similar results, their underlying principles are substantially different from each other (Bartual et al., 1985 and Odiyi et al., 2014). PCA captured all the 11 character as characters discriminating the genotypes while factor analysis identified all but Number of branches 6WAP, Vine diameter 6WAP, Petiole length 6WAP and Internode length 6WAP as important characters discriminating the genotypes. Vine length, number of branches and marketable leaf yield were identified as the most important characters by Factor analysis while PCA identified marketable leaf yield, vine length and number of branches as the most important characters. This findings conforms with the work of Bramel et al. (1984); Nair et al. (1998); Makinde and Ariyo (2010); Nassir and Ariyo (2007). The configuration of the genotypes along the axes of PC1, PC2 and PC3 shows that 


\section{International Journal of Engineering Applied Sciences and Technology, 2019 \\ Vol. 4, Issue 7, ISSN No. 2455-2143, Pages 211-216 \\ Published Online November 2019 in IJEAST (http://www.ijeast.com)}

genotype L4, N4, N3, O1, E1, A1, N1 and A3 were most distant from all other genotypes and are high yielding in terms of vine length, number of branches and leaf size therefore these genotypes can be selected directly. This corresponds with the findings of Odiyi et al. (2014) in fluted pumpkin.

Table 2: Eigen values, factor scores, communality, percent and cumulative variance of 10 studied characters of Corchorus from the factor analysis.

\begin{tabular}{|c|c|c|c|c|c|}
\hline \multirow{2}{*}{ Characters } & \multicolumn{4}{|c|}{ Factor } & \multirow{2}{*}{$\begin{array}{l}\text { Commun } \\
\text { ality }\end{array}$} \\
\hline & 1 & 2 & 3 & 4 & \\
\hline $\begin{array}{l}\text { Days to } \\
\text { emergence }\end{array}$ & 0.4 & 0.36 & -0.51 & 0.58 & 0.87 \\
\hline $\begin{array}{l}\text { Vine length } \\
2 \mathrm{WAP}(\mathrm{cm})\end{array}$ & 0.77 & -0.1 & -0.21 & 0.27 & 0.72 \\
\hline $\begin{array}{l}\text { Number of } \\
\text { leaves } \\
\text { 2WAP }\end{array}$ & 0.78 & -0.05 & 0.23 & -0.3 & 0.74 \\
\hline $\begin{array}{l}\text { Vine length } \\
6 \mathrm{WAP}(\mathrm{cm})\end{array}$ & 0.73 & 0.61 & 0.05 & -0.05 & 0.91 \\
\hline $\begin{array}{l}\text { Number of } \\
\text { leaves } \\
6 \mathrm{WAP}\end{array}$ & 0.7 & 0.43 & 0.27 & 0.21 & 0.8 \\
\hline $\begin{array}{l}\text { Number of } \\
\text { branches } \\
\text { 6WAP }\end{array}$ & 0.38 & -0.17 & 0.66 & 0.15 & 0.63 \\
\hline $\begin{array}{l}\text { Vine } \\
\text { diameter } \\
\text { 6WAP }(\mathrm{cm})\end{array}$ & 0.17 & -0.02 & 0.53 & 0.56 & 0.62 \\
\hline $\begin{array}{l}\text { Leaf length } \\
6 \mathrm{WAP}(\mathrm{cm})\end{array}$ & 0.82 & -0.51 & -0.1 & -0.06 & 0.95 \\
\hline $\begin{array}{l}\text { Leaf width } \\
6 \mathrm{WAP}(\mathrm{cm})\end{array}$ & 0.8 & -0.54 & -0.19 & 0 & 0.97 \\
\hline $\begin{array}{l}\text { Leaf area } \\
6 \text { WAP }\left(\mathrm{cm}^{2}\right) \\
\text { Petiole }\end{array}$ & 0.83 & -0.51 & -0.16 & -0.05 & 0.98 \\
\hline $\begin{array}{l}\text { length } \\
6 \mathrm{WAP}(\mathrm{cm})\end{array}$ & 0.61 & 0.63 & -0.27 & -0.21 & 0.88 \\
\hline $\begin{array}{l}\text { Internode } \\
\text { length } \\
6 \mathrm{WAP}(\mathrm{cm})\end{array}$ & 0.59 & 0.32 & 0.25 & -0.43 & 0.63 \\
\hline $\begin{array}{l}\text { Proportion of } \\
\text { variance } \\
\text { accounted } \\
\text { for } \%\end{array}$ & 44.04 & 17.05 & 11.18 & 9.2 & \\
\hline $\begin{array}{l}\text { Cumulative } \\
\text { of variance } \\
\text { accounted } \\
\text { for } \%\end{array}$ & 44.04 & 61.09 & 72.27 & 81.47 & \\
\hline
\end{tabular}

Table 3: Eigen value, percentage variance accounted for and cumulative percentage for agronomic characters of the first five principal components.

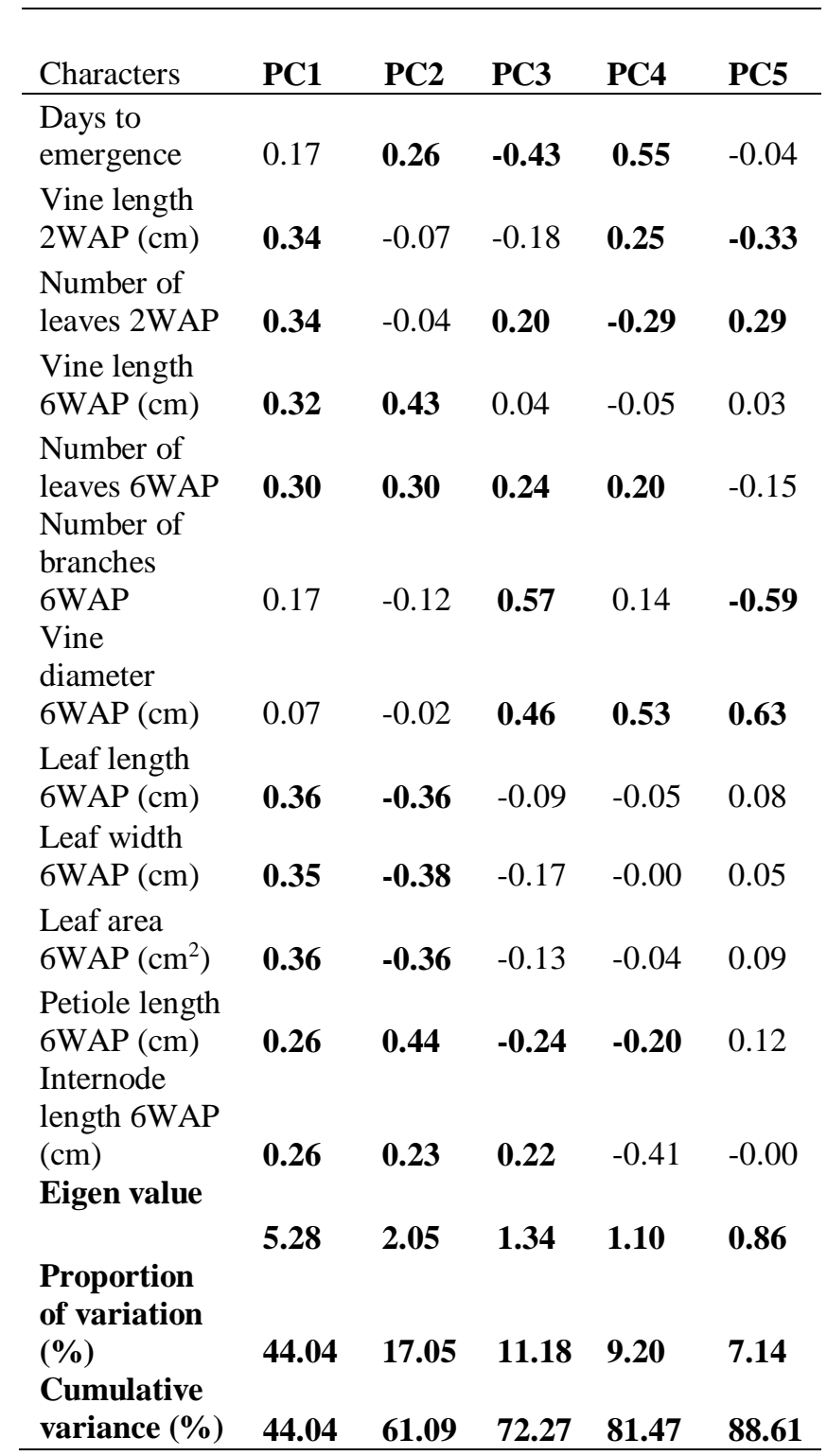


International Journal of Engineering Applied Sciences and Technology, 2019

Vol. 4, Issue 7, ISSN No. 2455-2143, Pages 211-216

Published Online November 2019 in IJEAST (http://www.ijeast.com)

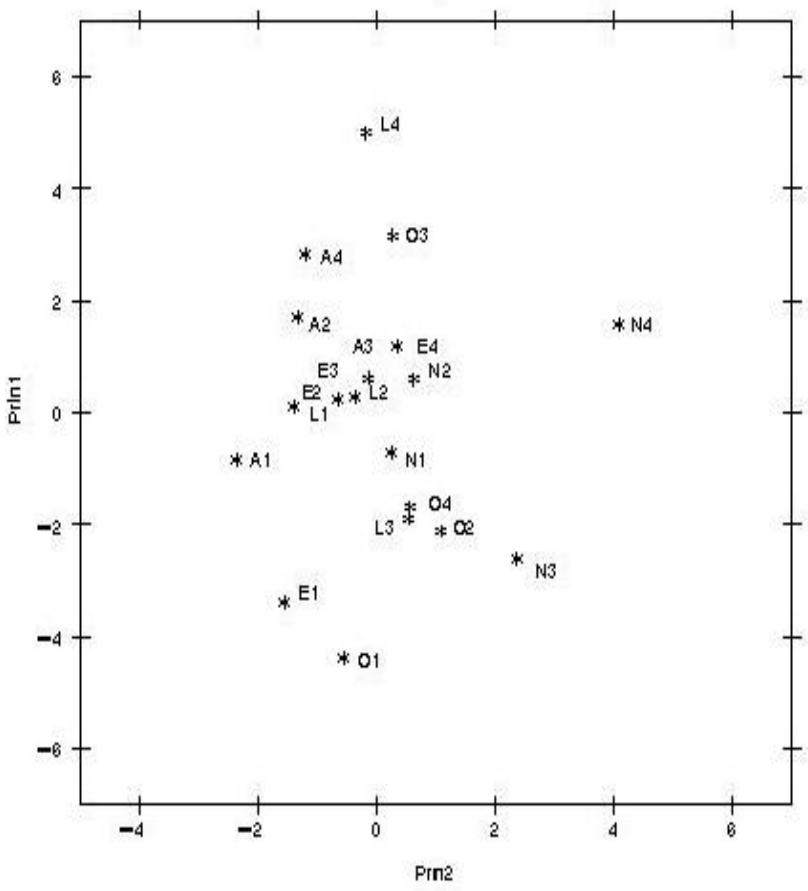

Fig. 1: Configuration of twenty genotypes under axes 1 and 2

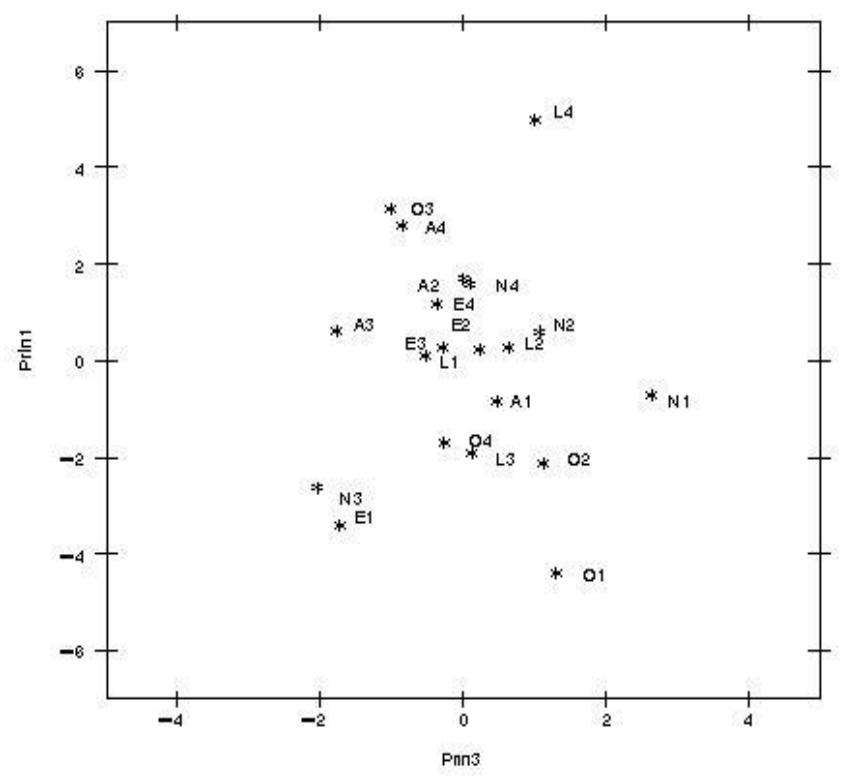

Fig. 2: Configuration of twenty genotypes under axes 1 and 3

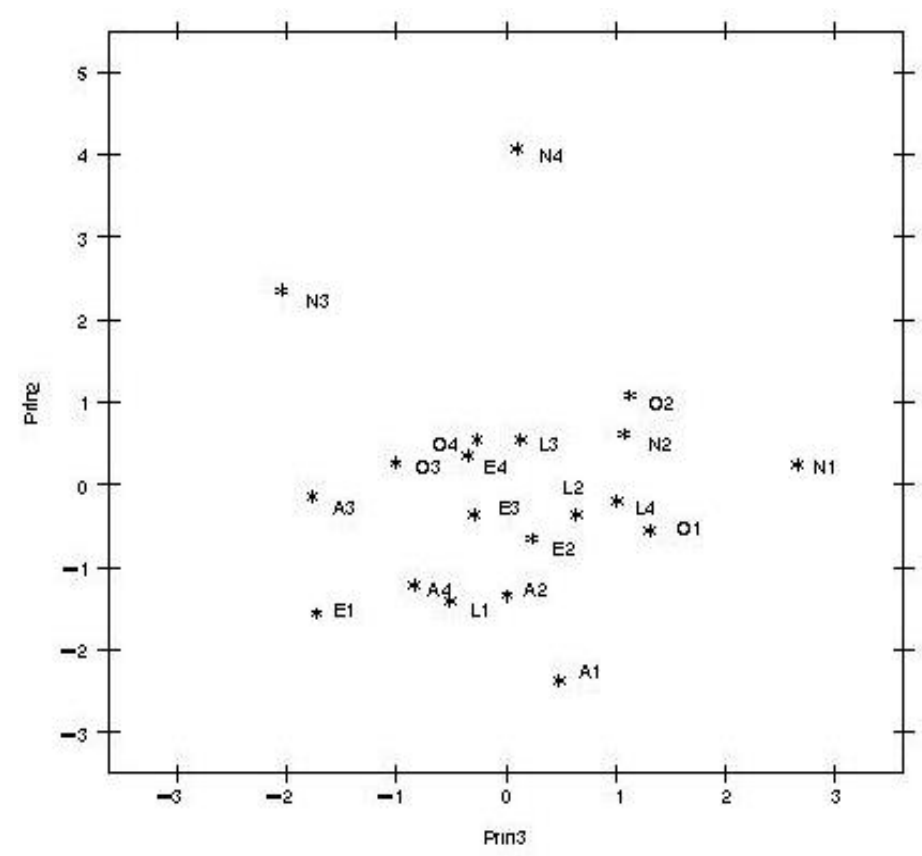

Fig. 3: Configuration of twenty genotypes under axes 2 and 3

\section{CONCLUSION}

This study shows that multivariate statistical methods are reliable in estimating accurate genetic diversity in crop breeding programmes because it allows comparison among the techniques used so as to determine which one captures most of the variation and provide clearer and informative display of the relative positions of the genotypes.

Factor analysis and principal component analysis jointly identified vine length, number of leaves, leaf length, leaf width and leaf area as important characters that cause variation among the genotypes. L4, N4, N3, O1, E1, A1, N1 and A3 are high yielding in terms of vine length, number of branches and leaf size therefore can be selected directly. Heterosis can also be achieved when these genotypes are crossed in subsequent breeding programmes.

\section{REFERENCES}

1. Akoroda M.O. (1990). Characteristics of Seeds on Variability and Heritability Studies in Telfairia occidentalis. Plant Breed. 1: (pp. 196-198).

2. Esiaba, R.O. (1983). Cultivating fluted pumpkin in Nigeria. World crops, March/April, (pp. 70-72).

3. Ehiangbonare, J. E. (2008). Conservation studied on Telfairia occidentalis Hook.F. indigenous plant used in enthnomedicinal treatment of anemia in Nigeria. African J. Agric. Research. 3(1): (pp. 74-77).

4. Irvine, A.C. (1969). Developmental Pattern of the Multiple Seedling Trait in Telfairia occidentalis 


\section{International Journal of Engineering Applied Sciences and Technology, 2019 \\ Vol. 4, Issue 7, ISSN No. 2455-2143, Pages 211-216 \\ Published Online November 2019 in IJEAST (http://www.ijeast.com)}

Hook, F. Sustainable Agric Environ. 5: (pp. 317325).

5. Kayode, A.A.A. and Kayode, O.T. (2011). Some medicinal values of Telfairia occidentalis: A review. American Journal of Biochemistry and Molecular Biology, 1: (pp. 30-38).

6. Okoli, B.E. and Mgbeogu, C.M. (1983). Fluted Pumpkin, Telfairia occidentalis, West Africa Vegetable crop. Econ. Bot., 37(2): (pp. 145-147).

7. Odiaka, N.I., Akoroda, M.O., Odiaka, E.C. (2008). Diversity and production methods of fluted pumpkin (Telfairia occidentalis Hook F.); Experience with vegetable farmers in Makurdi, Nigeria. Afr. $J$. Biotechnol. 7(8): (pp. 944-954).

8. Akanbi, B.W., Adebayo, A.T, Togun, A.O., Adeyeye, S.A., Olaniran, A.O. (2007). The use of compost extract as foliar spray nutrient source and botanical insecticide in Telfairia occidentalis. World J. Agric. Sci. 3(5): (pp. 642-652).

9. Odiyi, A.C., Fayeun, L.S., Makinde, S.C.O., Adetunji, A.T. (2014). Analysis of variation among fluted pumpkin (Telfairia occidentalis) accessions by factor analysis and principal component analysis. Canadian Journal of Plant Breeding, 2(2): (pp. 8086).

10. Rhodes, A. M. and Martins, F.W. (1972). Multivariate studies of variation in yams. J. Am. Soc. Horticult. Sci. 97: (pp. 685-688).

11. Ariyo, O.J., Aken'ova, M.E. and Fatokun, C.A. (1987). Plant character correlation and path analysis of pod yield in Okra (Abelmoschus esculentus). Euphytica, 36: (pp. 667-686).

12. Raji, A.A. (2003). Assessment of genetic diversity and heterotic relationship in African Improved and local cassava (Manihot esculentus Crantz) germplasm. J. Integrative Plant Biology, 50: (pp. 23).

13. Nassir, A.L. and Ariyo, O.J. (2007). Multivariate analysis of variation of field-planted upland rice (Oriza sativa L.) in a tropical habitat. Malaysian Applied Biology, 36(1): (pp. 47-57).

14. Makinde, S. C. O. and Ariyo, O. J. (2010). Multivariate analysis of genetic divergence in twenty two genotypes of groundnut (Arachis hypogaea L.). J. Plant Breeding and Crop Sci. 2(7): (pp. 192-204).

15. Cooley, W.W. and Lohnes, P.R. (1971). Multivariate data analysis. John Wiley \& Sons Inc. N.Y.

16. Bramel, P. J., Hinnz, P. N., Green, D.E. and Shibles, R.M. (1984). Use of principal factor analysis in the study of three stem termination types of soybean. Euphytica, 33: (pp. 387-400).

17. Fayeun L.S. (2011). Investigation into genetic diversity of the fluted pumpkin Telfairia occidentalis (Hook. F.) in Southern Nigeria. Unpublished M. Tech. Thesis, Federal University of Technology, Akure, Nigeria.
18. Fayeun, L.S. and Odiyi, A.C. (2012). Cluster analysis of genetic divergence in thirty- five genotypes of the fluted pumpkin (Telfairia occidentalis) collected from southern Nigeria. Proceedings of the 36th Annual conference of Genetics Society of Nigeria, held at University of Calabar, 15th-18th October, 2012. \{Editors: Uyoh EA, Iwo GA, Okon B, Ittah MA, Ibom LA, Etta H, Udensi O.\}: (pp. 197-206).

19. Ariyo, O.J. (1993). Genetic diversity in West African Okra (Abelmoschus callei L. (Chev.) StevelsMultivariate analysis of morphological and agronomical characteristics. Genetic Res. Crop Evol. 40: (pp. 25-32).

20. Ariyo, O.J. (1995). Genetic variability, correlation and path coefficient analysis of components of seed yield in cowpea (Vigna unguiculata (L) Walp). Pertan. J. Trop. Agric. Sci., 18(1): (pp. 63-69).

21. Nair, N.V., Ballakrishnan, R. and Screenivasan, T.V. (1998). Variability for quantitative traits in exotic hybrid germplasm of sugar cane. Gen. Res. And Crop Evol., 45: (pp. 459-464).

22. Wiley, E.O. (1981). Phylogenetics: The theory and practice of phylogenetics and systematic. John Wiley, New York.

23. Aremu, C.O., Adebayo, M.A, Ariyo, O.J, Adewale, B.D. (2007). Classification of genetic diversity and the choice of parents for hybridization in cowpea (Vigna unguiculata (L) Walp) for humid savanna ecology. African J. Biotechnology, 6(20): (pp. 23332339). 